\title{
Effect of exchanging Onobrychis viciifolia and Lotus corniculatus for Medicago sativa on ruminal fermentation and nitrogen turnover in dairy cows
}

\author{
A. Grosse Brinkhaus, ${ }^{*} \dagger$ G. Bee, ${ }^{*}$ P. Silacci, ${ }^{*}$ M. Kreuzer, $†$ and F. Dohme-Meier ${ }^{* 1}$ \\ *Agroscope, Institute for Livestock Sciences ILS, Tioleyre 4, 1725 Posieux, Switzerland \\ †ETH Zurich, Institute of Agricultural Science, Universitaetstrasse 2, 8092 Zurich, Switzerland
}

\begin{abstract}
The objective of the study was to determine the effect of feeding sainfoin (SF; Onobrychis viciifolia) and birdsfoot trefoil (BT; Lotus corniculatus), 2 temperate climate forage legumes that contain condensed tannins (CT), on ruminal fermentation and $\mathrm{N}$ turnover in dairy cows. Six ruminally cannulated multiparous dairy cows (milk yield $=40 \mathrm{~kg} / \mathrm{d} ; 36 \mathrm{~d}$ in milk) were used in a replicated $3 \times 3$ Latin square design. All animals were fed basal diets containing $20 \%$ pelleted SF ( $223 \mathrm{~g}$ of $\mathrm{CT} /$ $\mathrm{kg}$ of dry matter), BT (30.3 $\mathrm{g}$ of $\mathrm{CT} / \mathrm{kg}$ of dry matter), or alfalfa (AL) and concentrate to meet their predicted nutrient requirements. Each experimental period consisted of a 21-d adaptation period in a tiestall, followed by a 7 -d collection period in metabolic crates, where feces and urine were collected quantitatively. During the 7-d period, milk yield was recorded daily and milk samples were taken at each milking. Blood, ruminal fluid, and papillae were sampled on d 2 and 5 . The relative abundance of selected bacterial strains in ruminal fluid and the gene expression of transporter genes in the papillae were determined with quantitative PCR. Total volatile fatty acids and the abundance of the cellulolytic bacteria Prevotella spp. and Ruminococcus flavefaciens decreased with SF compared with AL. The relative gene expression of the monocarboxylate transporter 1 was increased with BT compared with AL and SF. Total yields of milk, milk fat, and milk protein were similar among treatments. The proportion of 18:3n-3 in milk fat was greater and those of 22:5n-3 and 22:6n-3 were lower with SF than with BT. The contents of urea $\mathrm{N}$ in blood $(2.71,3.45$, and $3.90 \mathrm{mmol} / \mathrm{L}$ for $\mathrm{SF}, \mathrm{AL}$, and $\mathrm{BT}$, respectively), milk $(79.8,100.1$, and $110.9 \mathrm{mg} / \mathrm{kg}$ for $\mathrm{SF}, \mathrm{AL}$, and $\mathrm{BT}$, respectively), and urine were lower
\end{abstract}

Received June 5, 2015.

Accepted February 2, 2016

${ }^{1}$ Corresponding author: frigga.dohme-meier@agroscope.admin.ch with SF than with $\mathrm{AL}$ and $\mathrm{BT}$, and a trend toward a lower ruminal ammonia content occurred with SF compared with BT. Intake and excretion of $\mathrm{N}$ with milk were similar among treatments, but urine $\mathrm{N}$ was lower with SF than with AL. The $\mathrm{N}$ excretion to $\mathrm{N}$ intake relation showed a shift in a part of urine $\mathrm{N}(17.5,20.8$, and $19.5 \%$ for $\mathrm{SF}, \mathrm{AL}$, and BT, respectively) to fecal $\mathrm{N}$ (45.2, 41.3, and $38.5 \%$ for $\mathrm{SF}, \mathrm{AL}$, and BT respectively) with SF compared with AL and BT. In conclusion, SF and $\mathrm{BT}$ differed in their effects on fermentation and milk fatty acid profile and SF also showed potential to decrease metabolic and environmental loads. The main reason for the different efficiency was likely a higher CT content of SF compared with BT.

Key words: condensed tannin, ruminal fermentation, microbial community, nitrogen loss

\section{INTRODUCTION}

Forage-based production systems for dairy cows are considered economically beneficial when compared with production systems with high-concentrate TMR, and they may have a positive effect on the environment because of the reduced need for fossil energy in feed production and transport (Dillon et al., 2005). However, feeding of forage-dominated diets to dairy cows may also involve risks because these feeds often contain more RDP than can be used by ruminal microbes, which causes excessive $\mathrm{NH}_{3}$ in the rumen. The absorption and metabolism of this $\mathrm{NH}_{3}$ then elevates the urea levels in the blood, milk, and urine (Roseler et al., 1993; Spek et al., 2013). Bruinenberg et al. (2002) reported a frequently high excretion of $\mathrm{N}$ in the urine due to the imbalance between dietary protein and energy content in herbage-fed cows. This excretion has adverse environmental effects (Dijkstra et al., 2013), and it may also increase the metabolic load, especially during early lactation, because of the extra energy consumption needed for detoxification of excessive ruminal ammonia 
by ureagenesis (Lobley et al., 1995). Furthermore, the reduced flux of (microbial) protein to the duodenum, as a consequence of low dietary supply of fermentable energy, is supposed to be a limiting factor for milk production in cows consuming herbage (Bruinenberg et al., 2002). Therefore, forage-based diets have to be designed in a way that must prevent excessive ruminal protein degradation and increase the amount of ruminal escape protein, thereby increasing the digestive and metabolic N efficiency.

One potential strategy to improve $\mathrm{N}$ utilization is to include forages containing condensed tannins $(\mathbf{C T})$ into dairy cow diets. These CT, which are polymers of flavanol (flavan-3-ol) units linked by carbon-carbon bonds, are known to form complexes with cellulose, hemicellulose, and pectin (McSweeney et al., 2001), and especially with dietary proteins (Hagerman and Butler, 1981). The complexes protect against ruminal degradation (Waghorn, 2008), resulting in a shift of $\mathrm{N}$ excretion from the urinary route to the feces (Carulla et al., 2005). The CT also influence ruminal biohydrogenation (BH) of UFA (Khiaosa-Ard et al., 2009). Furthermore, in vitro studies have shown that CT can bind to the cell coat polymers of ruminal bacteria, such as Butyrivibrio fibrisolvens, thereby decreasing the bacterial enzyme activity involved in the ruminal BH of dietary UFA (Jones et al., 1994). In addition, experiments in monogastric animals have shown that CT may damage the intestinal mucosa and decrease the absorption of AA (Waghorn, 2008). At present, no study has examined the effect of CT on the ruminal papillae of dairy cows or on the abundance of the transporter genes that are responsible for absorption of many ruminal degradation products.

A great wealth of CT-containing plant species exists in the tropics, whereas the list is far smaller for forage legumes growing in temperate climates. Promising temperate species include sainfoin (SF; Onobrychis viciifolia) and birdsfoot trefoil (BT; Lotus corniculatus). Experiments investigating the effect of CT from temperate climate legumes in general, and especially those of SF and BT, are plentiful for sheep (reviewed by Waghorn, 2008) but scarce for dairy cows. Hymes-Fecht et al. (2013) reported that the replacement of alfalfa (AL; Medicago sativa) silage by BT silage in a TMR improved performance and $\mathrm{N}$ utilization in lactating dairy cows. The dairy cows that either grazed a BT pasture (Harris et al., 1998; Turner et al., 2005) or were offered fresh BT in the barn (Woodward et al., 2000) also showed improved performance when compared with cows fed perennial ryegrass (Lolium perenne) and white clover (Trifolium repens). When feeding SF hay to dairy cows as supplement to herbage, Scharenberg et al. (2009) observed a low acceptance even though choice experiments indicated the palatability index was higher for SF than BT in sheep (Scharenberg et al., 2007b) and SF hay was preferred to BT hay in a pretest in nonlactating cows (Scharenberg et al., 2009). These opposing effects could be due to different contents of dietary CT (Hymes-Fecht et al., 2013), the CT structure, or both. The content and structure of CT can vary considerably among species (Mueller-Harvey, 2006) and within species (Azuhnwi et al., 2011) and can change in response to different environmental conditions, such as microclimate and soil quality (Tiemann et al., 2010).

In the present study, we assessed the potential for the inclusion of temperate climate CT legumes in diets for dairy cows by testing the following hypotheses: (1) replacing a non-CT legume such as AL by CT-containing legumes would modify ruminal fermentation in a way that would improve both $\mathrm{N}$ utilization and milk fatty acid profile, and (2) the level of improvement would differ between legume species (BT vs. SF) due to their differences in CT content and structure. The legumes were offered as pellets because in this form CT legumes are already used as nutraceuticals against digestive parasites in small ruminants (Hoste et al., 2015) and as a well-accepted supplement in dairy cow diets (Girard et al., 2016; Arrigo and Dohme, 2009)

\section{MATERIALS AND METHODS}

\section{Experimental Design, Animals, and Diets}

Six ruminally cannulated (Bar Diamond Inc., Parma, ID) multiparous Swiss Holstein-Friesian cows were blocked by milk yield and assigned randomly in a monofactorial design to 3 treatments in a replicated 3 $\times 3$ Latin square arrangement. At the beginning of the experiment, the cows were, on average, $36( \pm 18)$ DIM, had a BW of $716( \pm 45.0) \mathrm{kg}$, and produced $40( \pm 6) \mathrm{kg}$ of milk per day. Each of the 3 consecutive experimental runs consisted of a 21-d adaptation period, where the cows were individually stalled in a tiestall with rubber mat flooring, and a 7-d data collection period where each cow was kept in a metabolism crate equipped with a slatted floor. Prior to the experiment, the animals were accustomed to the metabolism crates for $1 \mathrm{~d}$. All procedures were conducted in accordance with the Swiss guidelines for animal welfare and were approved (No. 2012_38_FR) by the Animal Care Committee of the Canton Fribourg, Fribourg, Switzerland.

The cows received a basal diet consisting of a partial mixed ration (PMR; Table 1) including grass hay, corn silage, and Extrulin 135 (Nutri'Form SA, Hildisrieden, Switzerland; this product contains $60 \%$ extruded linseed and $40 \%$ wheat bran, and was added to increase the amount of PUFA in the diet). A barley-corn-wheat 
Table 1. Ingredients and chemical composition of the diets $\left(\right.$ means $\left.^{1} \pm \mathrm{SD}\right)$

\begin{tabular}{|c|c|c|c|}
\hline Item & \multicolumn{3}{|c|}{ Treatment $^{2}$} \\
\hline \multicolumn{4}{|l|}{ Ingredient $(\mathrm{g} / \mathrm{kg}$ of $\mathrm{DM})$} \\
\hline Hay & $417 \pm 51.7$ & $408 \pm 47.5$ & $391 \pm 48.1$ \\
\hline Corn silage & $229 \pm 28.4$ & $224 \pm 26.1$ & $215 \pm 26.5$ \\
\hline Extruded linseed $^{4}$ & $48.6 \pm 6.03$ & $47.6 \pm 5.54$ & $45.6 \pm 5.62$ \\
\hline \multicolumn{4}{|c|}{ Analyzed composition $^{5}$ ( $\mathrm{g} / \mathrm{kg}$ of DM, unless noted) } \\
\hline $\mathrm{DM}^{6}$ (g/kg of wet weight) & $770 \pm 4.1$ & $773 \pm 2.7$ & $774 \pm 3.1$ \\
\hline $\mathrm{OM}$ & $928 \pm 0.6$ & $932 \pm 0.1$ & $929 \pm 0.5$ \\
\hline $\mathrm{CP}$ & $142 \pm 0.5$ & $139 \pm 0.6$ & $149 \pm 0.3$ \\
\hline NDF & $428 \pm 7.7$ & $415 \pm 4.3$ & $410 \pm 5.7$ \\
\hline $\mathrm{ADF}$ & $241 \pm 3.3$ & $236 \pm 3.1$ & $230 \pm 2.2$ \\
\hline $18: 3 n-3$ & $14.5 \pm 0.49$ & $14.6 \pm 0.32$ & $14.8 \pm 0.30$ \\
\hline \multicolumn{4}{|c|}{ Calculated energy and protein supply ${ }^{7}$ (per $\mathrm{kg}$ of DM) } \\
\hline $\mathrm{NE}_{\mathrm{L}}(\mathrm{MJ})$ & $6.34 \pm 0.025$ & $6.36 \pm 0.012$ & $6.40 \pm 0.011$ \\
\hline $\operatorname{APDE}(\mathrm{g})$ & $92.2 \pm 0.27$ & $92.4 \pm 0.18$ & $95.4 \pm 0.15$ \\
\hline $\operatorname{APDN}(\mathrm{g})$ & $91.1 \pm 0.45$ & $89.4 \pm 0.34$ & $96.1 \pm 0.38$ \\
\hline
\end{tabular}

\footnotetext{
${ }^{1}$ Mean over the 3 periods of the Latin square.

${ }^{2} \mathrm{AL}=$ alfalfa; $\mathrm{SF}=$ sainfoin; and $\mathrm{BT}=$ birdsfoot trefoil.

${ }^{3} 60 \%$ hay, $33 \%$ corn silage, and $7 \%$ linseed.

${ }^{4}$ Extrulin 135 (Nutri'Form SA, Hildisrieden, Switzerland), containing 60\% extruded linseed and 40\% wheat bran.

${ }^{5}$ Means of 3 determinations per treatment.

${ }^{6}$ Means of 21 determinations per treatment.

${ }^{7}$ Calculated as described by Thanner et al. (2014). APD = absorbable protein at the duodenum when rumen fermentable energy (APDE) or nitrogen $(\mathrm{APDN})$ is limiting microbial protein synthesis in the rumen.
}

mixture (mixing ratio $=1: 1: 1$ ) and a soybean cakebased protein concentrate were also offered in amounts to meet each animal's individual predicted nutrient requirements (Agroscope, 2014), which resulted in some, but limited, individual variations in dietary ingredient proportions (Table 1). The cows also were fed $60 \mathrm{~g} / \mathrm{d}$ of $\mathrm{NaCl}$ and $40 \mathrm{~g} / \mathrm{d}$ of a mineral-vitamin mixture containing (per kg): Ca, 104 g; P, 56 g; Mg, 25 g; Na, 66 g; Zn, $1.3 \mathrm{~g}$; Se, $6.6 \mathrm{mg}$; I, $20 \mathrm{mg}$; Co; $3.3 \mathrm{mg}, \mathrm{Cu}, 160 \mathrm{mg}$; Mn, 620 mg; vitamin A, 200,000 IU; vitamin $\mathrm{D}_{3}, 16,000$ $\mathrm{IU}$; vitamin E, 1,300 $\mathrm{mg}$; and biotin, $67 \mathrm{mg}$.

The experimental variation was generated by offering either AL (Medicago sativa L. 'Sanditi'), SF (Onobrychis viciifolia L. 'Perly'), or BT (Lotus corniculatus L. 'Polom') in amounts representing approximately 20\% of the basal diet. The legumes were grown at Posieux, Switzerland (650 $\mathrm{m}$ altitude), harvested as the second cut after $49 \mathrm{~d}$ of regrowth, at the stage of early flowering, and wilted on the field for $24 \mathrm{~h}$. For the pelleting process, the wilted legumes were chopped to 5 to $8 \mathrm{~cm}$ before drying for $4 \mathrm{~min}$ at $700^{\circ} \mathrm{C}$. Subsequently, the forage was milled, at a temperature of approximately $80^{\circ} \mathrm{C}$, to pass a $3-\mathrm{mm}$ sieve and pressed into pellets of 2 $\mathrm{cm}$ in length and $8 \mathrm{~mm}$ in diameter.

During the adaptation periods, ad libitum intake of the basal diet of each cow was determined and used as a basis for offering a constant amount of the basal diet and concentrate ingredients to the cows during each collection period. Pellets and concentrate ingredients were offered together in 2 equal meals, at 0630 and $1430 \mathrm{~h}$, followed by the PMR at 0700 and $1700 \mathrm{~h}$. Cows had continuous access to tap water.

\section{Data Recording and Sample Collection}

Feed intake was recorded daily. Samples of pellets and concentrates were taken every day and samples of hay, corn silage, and linseed were taken every second day of each collection period and pooled over each period for analysis of chemical composition. The PMR was analyzed daily for DM by oven drying at $105^{\circ} \mathrm{C}$ for $3 \mathrm{~h}$. For chemical analysis, corn silage and feces samples were lyophilized (Christ, Osterode, Germany); all other feed samples were dried at $60^{\circ} \mathrm{C}$ for $24 \mathrm{~h}$. All samples 
were ground to pass a 1-mm screen (Brabender mill, Brabender, Duisburg, Germany).

The BW of the cows was determined twice a day during the adaptation period, after milking in the milking parlor. During the collection periods, cows were milked in their metabolism crates. Milk yields were determined at each milking (0500 and $1600 \mathrm{~h}$ ) and milk samples were taken from each cow and pooled per day. Daily samples were subdivided. One subsample was preserved in Broad Spectrum Microtabs (Gerber Instruments $\mathrm{AG}$, Effretikon, Switzerland) and stored at $5^{\circ} \mathrm{C}$ for later infrared analysis of milk gross constituents. A second subsample was stored at $-20^{\circ} \mathrm{C}$ for later analysis of urea. Milk samples were also pooled by cow across the entire collection period and stored at $-20^{\circ} \mathrm{C}$ for later analysis of $\mathrm{N}$ content. Daily milk samples were also taken for each cow on d 1,4 , and 7 of each collection period and stored at $-20^{\circ} \mathrm{C}$ for later analysis of fatty acid composition.

Feces and urine were collected quantitatively every day of the collection period. The urine was collected in urinals attached around the vulva with Velcro straps glued to the shaved skin. The urine was acidified directly with $2.5 \mathrm{M}$ sulfuric acid to avoid N losses. Approximately $90 \mathrm{~g}$ of feces and $150 \mathrm{~mL}$ of urine were taken daily, pooled by cow across the entire collection period, and stored continuously at $-20^{\circ} \mathrm{C}$ for later analysis.

On $\mathrm{d} 2$ and 5 of the collection period, at 0700 and $1700 \mathrm{~h}$, before offering the PMR, blood was sampled from the jugular vein using serum tubes (Greiner BioOne, Kremsmuenster, Austria). After sampling, the tubes were stored for $1 \mathrm{~h}$ at room temperature and then centrifuged for 15 and $2 \mathrm{~min}$ at 3,000 and 4,000 $\times g$, respectively, at room temperature. The retrieved serum was stored at $-20^{\circ} \mathrm{C}$ for later analysis of urea. On the same days and at the same time points, ruminal fluid, particulate matter content, and papillae were also taken. The ruminal fluid was collected from the ventral rumen using a tube equipped with a terminal cone fitted with a $1-\mathrm{mm}$ pore size sieve. Samples were cooled on ice directly after sampling. For later analysis of VFA and $\mathrm{NH}_{3}$ contents, $10 \mathrm{~mL}$ of ruminal fluid were mixed with $0.2 \mathrm{~mL}$ of $50 \%$ (vol/vol) sulfuric acid or with $0.2 \mathrm{~mL}$ of $50 \%$ ( $\mathrm{vol} / \mathrm{vol}$ ) trichloroacetic acid for analysis of VFA and $\mathrm{NH}_{3}$, respectively, and stored at $-20^{\circ} \mathrm{C}$. For the later determination of protozoal counts, $0.5 \mathrm{~mL}$ of ruminal fluid was mixed with $0.5 \mathrm{~mL}$ of $6 \%$ (vol/vol) formalin. Particulate matter was obtained by taking approximately $150 \mathrm{~g}$ of material by hand from the ventral rumen and squeezing slightly to release ruminal fluid. The remainder was immediately frozen at $-20^{\circ} \mathrm{C}$. Ruminal papillae were taken through the rumen cannula from the area of the atrium ruminis in the ventral rumen. Every biopsy consisted of 3 to 5 papillae that were removed using only the fingers while wearing gloves. The papillae were washed in PBS solution and then stored in RNAlater TissueProtect solution (Qiagen, Venlo, the Netherlands) at $4^{\circ} \mathrm{C}$.

\section{General Laboratory Analysis}

The DM and OM contents of feeds and feces were determined gravimetrically by oven-drying at $105^{\circ} \mathrm{C}$ and ashing at $550^{\circ} \mathrm{C}$ for 3 and $4 \mathrm{~h}$, respectively. Contents of ADF (AOAC International, 1995; procedure 973.18) and NDF (AOAC International, 1995; procedure 2002.4) were analyzed using the Ankom fiber analyzer (Ankom Technology Corporation, Fairport, NT), where NDF was analyzed with heat-stable amylase and sodium sulfite. Both ADF and NDF were expressed without residual ash, determined by $1 \mathrm{~h}$ of incineration. The total $\mathrm{N}$ contents of feeds, feces, urine, and milk were analyzed by the Kjeldahl method (AOAC International, 1995; procedure no. 988.05) and multiplied by 6.25 for the feed, to calculate the $\mathrm{CP}$ content. The dietary contents of $\mathrm{NE}_{\mathrm{L}}$ and absorbable protein in the duodenum were calculated as described by Thanner et al. (2014). The total fatty acid contents were extracted with toluene and $5 \% \mathrm{HCl}$ dissolved in methanol for $3 \mathrm{~h}$ at $70^{\circ} \mathrm{C}$, with methyl nonadecanoate as an internal standard. After extraction, the samples were purified with a solid phase extraction cartridge (Merck, Darmstadt, Germany) and fatty acid composition was determined by GC on a $15-\mathrm{m} \times 0.1-\mathrm{mm}$ column (Supelcowax, Sigma-Aldrich, St. Louis, MO) and flame ionization detection (Agilent 6850, Agilent Technologies, Santa Clara, CA). The contents of total, soluble, protein-bound, and fiber-bound CT of the SF and BT pellets were analyzed using the HCl-butanol method described by Terrill et al. (1992). The CT standards were prepared in advance from fresh SF and BT by extraction with acetone and water $(7: 3, \mathrm{vol} / \mathrm{vol})$ and purification on a Sephadex column (Sigma-Aldrich). Total phenols were analyzed by quantification of the phenolic hydroxyl groups with the Folin-Ciocalteau assay, according to Salminen and Karonen (2011), and were expressed as tannic acid equivalents.

Milk samples were analyzed for fat, protein, and lactose content using Fourier transformed infrared spectrometry (Milkoscan FT 6000, Foss, Hillerød, Denmark). The MUN content was determined using the UreaFil test kit (MEA 549 EC Milk Urease, Eurochem, Moscow, Russia). The fatty acid composition was determined by dissolving the milk fat in hexane, followed by transesterification and subsequent separation of the fatty acids on a capillary column (CP-SIL 88, $100 \mathrm{~m}$, 0.25-mm i.d., 0.20- $\mu \mathrm{m}$ film thickness, P.H. Stehelin \& Cie AG, Basel, Switzerland) by GC (Agilent 6890, Agi- 
lent Technologies), following the procedure described by Ampuero-Kragten et al. (2014).

The ruminal VFA profile was analyzed by HPLC (Dionex, Dionex Corporation, Sunnyvale, CA) with a Shodex detector (Showa Denko K.K, Minato, Japan). Ruminal $\mathrm{NH}_{3}$ was determined colorimetrically with a commercial test kit (S 180, BioMerieux, Geneva, Switzerland). Ruminal ciliates were counted with a $0.1-\mathrm{mm}$ Bürker counting chamber (LO Laboroptic Ltd., Lancing, UK) and were characterized as entodiniomorphid and holotrich cells. Urinary and serum urea contents were determined by enzymatic treatment with urease (EC 3.5.1.5) and glutamate dehydrogenase (EC 1.4.1.2) using a commercial test kit (No. 61974 BioMerieux, Marcy l'Etoile, France).

\section{DNA Extraction and PCR Analysis of Ruminal Samples}

The genomic DNA from ruminal microbes was extracted from particulate ruminal content using a DNA Stool Mini Kit (Qiagen). The extractions were carried out following the manufacturer's protocol (version 06/2012, Qiagen) with minor modifications. Briefly, 1.4 $\mathrm{mL}$ of lysis buffer was added to $100 \mathrm{mg}$ of lyophilized material. The samples were then incubated at $95^{\circ} \mathrm{C}$ for $15 \mathrm{~min}$. After centrifugation $(2,000 \times g$ for $3 \mathrm{~min}$ at room temperature), the samples were incubated again at $65^{\circ} \mathrm{C}$ for $10 \mathrm{~min}$ in presence of ribonuclease $\mathrm{A}$ (EC 3.1.27.5) and proteinase K (EC 3.4.21.64), followed by purification on QIAamp spin columns (Qiagen). The DNA was eluted by applying $100 \mu \mathrm{L}$ of the elution buffer to the top of the columns. The DNA content was determined using a NanoDrop spectrometer (ND1000, Witec AG, Luzern, Switzerland), and the samples were then diluted with nuclease-free water to $4 \mathrm{ng} / \mu \mathrm{L}$. Primers for the bacteria and for the transporter genes were purchased in desalted quality (Eurogentec, Seraing, Belgium, and Microsynth, Balgach, Switzerland). Primers not taken from the literature were generated with the National Center for Biotechnology Information's Primer-BLAST software tool (Ye et al., 2012). Generally, the primers were designed based on the gene coding for the $16 \mathrm{~S}$ ribosomal RNA of a certain species, while performing a BLAST search (http://blast.ncbi. nlm.nih.gov/Blast.cgi) against all bacterial genomes available. The target and housekeeping gene primers are shown in Appendix Table A1. All reactions regarding the bacteria were carried out in duplicate within an Eco Illumina Real-Time PCR System (Illumina Inc., San Diego, CA) in a reaction volume of $20 \mu \mathrm{L}$. The amount of $16 \mathrm{~S}$ ribosomal DNA of the bacteria was measured with SYBR green technology with the Kapa SYBR Fast Universal $2 \times$ quantitative PCR Master Mix
(Kapa Biosystems, Woburn, MA). The thermal profile consisted of $5 \mathrm{~min}$ of activation at $95^{\circ} \mathrm{C}$, followed by a 40-cycle, 3-step PCR with $10 \mathrm{~s}$ of denaturation at $95^{\circ} \mathrm{C}$, $20 \mathrm{~s}$ of annealing at $60^{\circ} \mathrm{C}$, and $20 \mathrm{~s}$ of extension at $72^{\circ} \mathrm{C}$. The assay specificity was ensured by generating a melting curve at the very end by slow denaturation through heating from 55 to $95^{\circ} \mathrm{C}$. The amplification efficiency (E) for each primer pair was calculated using a mixture of DNA derived from 6 different random fibrous samples; this mixture was diluted at least 5-, $10-$, and 50-fold, as well as 100- and 500-fold for moreabundant bacteria, and amplified as described above. The efficiency was calculated automatically by the associated EcoStudy software (Illumina Inc.), where the quantification cycle $(\mathrm{Cq})$ values and amount of template are plotted against each other, a linear regression was calculated, and the efficiency was determined according to the equation: $\mathrm{E}=10^{(-1 / \text { slope })}$. For the $16 \mathrm{~S}$ ribosomal DNA (target gene, T) of the selected species, the percentage $(\mathrm{P})$ in relation to the total bacterial $16 \mathrm{~S}$ ribosomal DNA (reference gene, $\mathrm{R}$ ) was calculated using the following formula:

$$
\mathrm{P}=\frac{\mathrm{E}_{\mathrm{R}}^{\mathrm{Cq}(\mathrm{R})}}{\mathrm{E}_{\mathrm{T}}^{\mathrm{Cq}(\mathrm{T})} .}
$$

The expression of the transporter genes was determined by extracting the total RNA from the papillae using the Nucleospin RNA XS kit (Macherey-Nagel, Dueren, Germany), following the manufacturer's procedure. Briefly, 3 to 5 papillae were thawed and homogenized in a MiniLys (Bertin, CNIM Group, Paris, France) using a CK14 Precellys Lysing Kit (Precellys 24, CNIM Group) in $0.3 \mathrm{~mL}$ of lysis buffer. The total RNA was further extracted and the RNA content was determined using a NanoDrop Spectrophotometer (ND-1000, Witec AG). A 250-ng sample of RNA was used for reverse transcription with the Quantitect Reverse Transcription kit (Qiagen). The resulting reaction product was diluted 1:1 with water free of RNA-degrading enzymes before further analysis. The expression of the genes for the monocarboxylate co-transporter isoform 1 (MCT1), the sodium hydrogen exchanger isoforms 1 and 3 (NHE1 and NHE3, respectively), and the urea transporter B (UTB1) in the ruminal papillae was determined with a quantitative real-time PCR, using a KAPA Sybr Fast quantitative PCR Kit (Kapa Biosystems) with an Eco Ilumina-Real Time PCR System (Illumina Inc.). The program consisted of a preincubation step at $95^{\circ} \mathrm{C}$ for $5 \mathrm{~min}$, followed by 40 cycles of $5 \mathrm{~s}$ at $95^{\circ} \mathrm{C}$, and 20 $\mathrm{s}$ at $40^{\circ} \mathrm{C}$. The expression of each targeted gene was evaluated using the $\Delta \mathrm{Ct}$ (cycle threshold) method and normalized using GAPDH as housekeeping gene. All 
the calculations were performed using the EcoStudy software (Illumina Inc.).

\section{Statistical Analysis}

Data collected over several days were averaged per cow per period before statistical analysis. The results are presented in the tables as least squares means and standard error of the mean. Data were subjected to ANOVA using the MIXED procedure of the SAS 9.2 software (SAS Institute Inc., Cary, NC), according to the following model:

$$
\mathrm{Y}_{i j k l}=\mu+\mathrm{t}_{j}+\mathrm{s}_{i}+\mathrm{p}_{k}+\mathrm{c}_{l}+\mathrm{e}_{i j k l},
$$

where $\mathrm{Y}_{i j k l}$ represents the dependent variable; $\mu$ represents the least squares mean; $\mathrm{t}_{j}$ represents the fixed effect of the treatment $(j=\mathrm{Al}, \mathrm{SF}, \mathrm{BT}) ; \mathrm{s}_{i}$ represents the fixed effect of the sequence in the Latin square $(i$ $=1,2,3) ; \mathrm{p}_{k}$ represents the fixed effect of the Latin square period $(k=1,2,3) ; \mathrm{c}_{l}$ represents the random effect of the cow; and $\mathrm{e}_{i j k l}$ represents the random error. When samples were taken at different time points during the sampling period, they were treated as repeated measurements and the statement was included in the model reading:

$$
\mathrm{Y}_{i j k l}=\mu+\mathrm{t}_{i}+\mathrm{r}_{j}+(\mathrm{tr})_{i j}+\mathrm{p}_{k}+\mathrm{c}_{l}+\mathrm{e}_{i j k l},
$$

where, in addition to the elements explained above, $\mathrm{r}_{j}$ represents the time point $(j=1,2)$ and $(\operatorname{tr})_{i j}$ represents the effect of the interaction between treatment $i$ and time $j$. The least squares means of the treatment groups, but not of the time points, are reported in the tables, because if an effect of time point (morning and evening) occurred, it represented the known diurnal variation. No interactions between treatment groups and time points were found; therefore, $P$-values were not reported. Degrees of freedom for the first model were determined using the Kenward-Roger option. Multiple comparisons among means were calculated with both models using Tukey's procedure. Significance was declared at $P<0.05$ and trends were discussed at $P<0.10$.

\section{RESULTS}

The chemical composition varied among the 3 legume pellet types with respect to contents of $\mathrm{CP}$, total fatty acids, and 18:2n-6; these were highest in BT, followed by AL and SF (Table 2). The content of 18:3n-3 was highest with BT and lowest with AL, whereas SF took an intermediate position. The AL pellets had the highest and SF the lowest NDF and ADF content, whereas the BT pellets took an intermediate position. The contents of total $\mathrm{CT}$ and of all $\mathrm{CT}$ fractions were higher in SF than in BT, and we assumed that AL contained

Table 2. Chemical composition of the Medicago sativa, Onobrychis viciifolia, and Lotus corniculatus pellets

\begin{tabular}{|c|c|c|c|}
\hline \multirow[b]{2}{*}{ Item } & \multicolumn{3}{|c|}{ Pellets $^{2}$} \\
\hline & $\mathrm{AL}$ & $\mathrm{SF}$ & BT \\
\hline \multicolumn{4}{|c|}{ Analyzed composition ( $\mathrm{g} / \mathrm{kg}$ of $\mathrm{DM})$} \\
\hline $\mathrm{OM}$ & $873 \pm 5.4$ & $895 \pm 2.1$ & $881 \pm 1.4$ \\
\hline $\mathrm{CP}$ & $182 \pm 3.6$ & $153 \pm 1.7$ & $208 \pm 2.3$ \\
\hline NDF & $421 \pm 21.9$ & $367 \pm 3.8$ & $380 \pm 4.7$ \\
\hline $\mathrm{ADF}$ & $327 \pm 1.2$ & $302 \pm 0.5$ & $306 \pm 0.1$ \\
\hline Total fatty acids & $27.4 \pm 1.95$ & $26.7 \pm 0.58$ & $33.9 \pm 0.84$ \\
\hline $16: 0$ & $4.11 \pm 0.183$ & $4.23 \pm 0.042$ & $5.09 \pm 0.123$ \\
\hline 18:0 & $0.65 \pm 0.031$ & $0.57 \pm 0.023$ & $0.48 \pm 0.020$ \\
\hline $18: 1 n-9$ & $0.79 \pm 0.227$ & $0.99 \pm 0.050$ & $0.96 \pm 0.076$ \\
\hline $18: 2 \mathrm{n}-6$ & $4.60 \pm 0.269$ & $4.33 \pm 0.101$ & $5.87 \pm 0.138$ \\
\hline $18: 3 n-3$ & $9.74 \pm 1.506$ & $12.02 \pm 0.294$ & $15.91 \pm 0.526$ \\
\hline \multicolumn{4}{|l|}{ Condensed tannins } \\
\hline Total & $\mathrm{NA}^{3}$ & $223 \pm 29.0$ & $30.3 \pm 2.93$ \\
\hline Soluble & NA & $141.8 \pm 6.31$ & $11.5 \pm 1.79$ \\
\hline Protein-bound & NA & $65.0 \pm 26.83$ & $14.4 \pm 1.61$ \\
\hline Fiber-bound & NA & $16.5 \pm 1.82$ & $4.4 \pm 0.59$ \\
\hline Total phenols ${ }^{4}$ & $9.70 \pm 0.217$ & $32.41 \pm 9.752$ & $16.33 \pm 1.931$ \\
\hline
\end{tabular}
$\left(\right.$ means $\left.^{1} \pm \mathrm{SD}\right)$ 
Table 3. Effects of the type of legume pellets on feed and nutrient intake, and total-tract digestibility

\begin{tabular}{|c|c|c|c|c|c|}
\hline \multirow[b]{2}{*}{ Item } & \multicolumn{3}{|c|}{ Treatment $^{1}$} & \multirow[b]{2}{*}{ SEM } & \multirow[b]{2}{*}{$P$-value } \\
\hline & $\mathrm{AL}$ & $\mathrm{SF}$ & $\mathrm{BT}$ & & \\
\hline \multicolumn{6}{|c|}{ Daily intake per cow (kg, unless noted) } \\
\hline Total DM & 21.5 & 21.2 & 21.2 & 1.31 & 0.82 \\
\hline Partial mixed ration & 14.9 & 14.3 & 13.8 & 1.10 & 0.38 \\
\hline Legume pellets & 3.53 & 3.43 & 3.48 & 0.158 & 0.18 \\
\hline Concentrate $^{2}$ & 3.11 & 3.49 & 3.87 & 0.947 & 0.36 \\
\hline $\mathrm{OM}$ & 20.0 & 19.7 & 19.7 & 1.23 & 0.88 \\
\hline $\mathrm{ADF}$ & 5.18 & 4.98 & 4.88 & 0.304 & 0.28 \\
\hline NDF & 9.22 & 8.76 & 8.72 & 0.533 & 0.26 \\
\hline Total fatty acids (g) & 952 & 934 & 956 & 55.9 & 0.75 \\
\hline $16: 0$ & 111 & 110 & 113 & 7.2 & 0.56 \\
\hline 18:0 & 20.2 & 19.5 & 19.0 & 1.10 & 0.27 \\
\hline $18: 1 n-9$ & 121 & 121 & 121 & 7.9 & 0.99 \\
\hline $18: 2 \mathrm{n}-6$ & 279 & 279 & 288 & 22.2 & 0.67 \\
\hline $18: 3 n-3$ & 312 & 308 & 315 & 21.1 & 0.85 \\
\hline Condensed tannins $(\mathrm{g})$ & $\mathrm{NA}^{3}$ & $754^{\mathrm{a}}$ & $107^{\mathrm{b}}$ & 31.4 & $<0.001$ \\
\hline \multicolumn{6}{|l|}{ Digestibility (\%) } \\
\hline $\mathrm{OM}$ & 68.6 & 70.1 & 71.8 & 2.40 & 0.18 \\
\hline NDF & 64.9 & 67.1 & 68.4 & 3.21 & 0.19 \\
\hline $\mathrm{ADF}$ & $57.3^{\mathrm{y}}$ & $60.4^{\mathrm{xy}}$ & $64.3^{\mathrm{x}}$ & 4.11 & 0.07 \\
\hline $\mathrm{N}$ & $58.7^{\mathrm{xy}}$ & $54.8^{\mathrm{y}}$ & $61.5^{\mathrm{x}}$ & 2.86 & 0.09 \\
\hline
\end{tabular}

${ }^{\mathrm{a}, \mathrm{b}}$ Means within a row with different superscripts differ $(P<0.05)$.

${ }^{\mathrm{x}, \mathrm{y}}$ Means within a row with different superscripts tend to differ $(P<0.10)$.

${ }^{1} \mathrm{AL}=$ alfalfa; $\mathrm{SF}=$ sainfoin; $\mathrm{BT}=$ birdsfoot trefoil.

${ }^{2}$ Consists of cereal mix and protein concentrate.

${ }^{3}$ Not analyzed.

a negligible concentration of $\mathrm{CT}$. Total phenol content was highest in SF followed by BT and AL.

Daily total DMI did not differ among treatments (Table 3). The same was true for the daily intake of $\mathrm{OM}, \mathrm{ADF}$, and NDF, as well as total and individual fatty acids. The daily intake of $\mathrm{CT}$ was higher $(P<$ 0.01) for SF than for BT. The total-tract digestibility of $\mathrm{OM}$ and $\mathrm{NDF}$ did not differ among treatments, but the ADF digestibility showed a trend to being higher $(P<0.10)$ for BT than for AL, whereas SF took an intermediate position. The apparent total-tract $\mathrm{N}$ digestibility showed a trend to being higher $(P<0.10)$ for $\mathrm{BT}$ than for $\mathrm{SF}$, whereas $\mathrm{AL}$ took an intermediate position.

Cows in the different treatment groups produced similar amounts of milk, with similar percentages of fat and lactose, and consequently secreted similar amounts of fat and lactose per day (Table 4). Milk protein percentage was greater $(P<0.05)$ for cows fed BT than for cows fed SF, whereas cows fed AL took an intermediate position. However, the numerically lower milk yield of BT compared with SF cows made this difference insignificant when protein was expressed as a daily yield. The milk of cows fed SF had a lower content of MUN $(P<0.01)$ when compared with the MUN of cows fed $\mathrm{BT}$, whereas cows fed AL took an intermediate position.
The fatty acid composition of the milk fat was similar among treatments, with a few exceptions. One was that the proportion of $18: 1 \mathrm{n}-9$ in milk fat was greater $(P<0.05)$ with SF than with AL, whereas BT took an intermediate position. The proportion of 18:3n-3 also tended to be higher $(P<0.10)$ with SF than with BT, and AL took an intermediate position. In contrast, the proportions of $20: 4 \mathrm{n}-6$ tended to be high $(P<0.10)$ with AL and low with BT, and SF took an intermediate position. The proportions of 22:6n-3 and 22:5n-3 $(P<$ $0.10)$ tended to be lowest with SF and highest with $\mathrm{BT}$, and AL again took an intermediate position. The transfer rate of 18:3n-3 was also numerically higher ( $P$ $=0.29)$ with $\mathrm{SF}(5.87 \%)$ than with $\mathrm{AL}(4.96 \%)$ and BT (4.81\%).

The BUN levels were lower in SF-fed cows $(P<0.01)$ than in cows fed AL and BT (Table 5). Concomitantly, ruminal ammonia $\mathrm{N}$ content tended to be lower $(P<$ $0.10)$ in cows fed SF than in those fed BT, with intermediate values seen in AL cows. Total VFA content was lower $(P<0.05)$ for SF cows than in AL cows, but not in BT cows. No treatment differences were observed for the ruminal VFA profile, except for the proportion of valerate, which was lower $(P<0.05)$ for SF cows than for BT cows but not for AL cows. Counts of total ciliate protozoa and entodiniomorphids were greater $(P<$ 0.05) for SF cows than for BT cows, whereas AL cows 
Table 4. Effect of the type of legume pellets on milk yield and composition

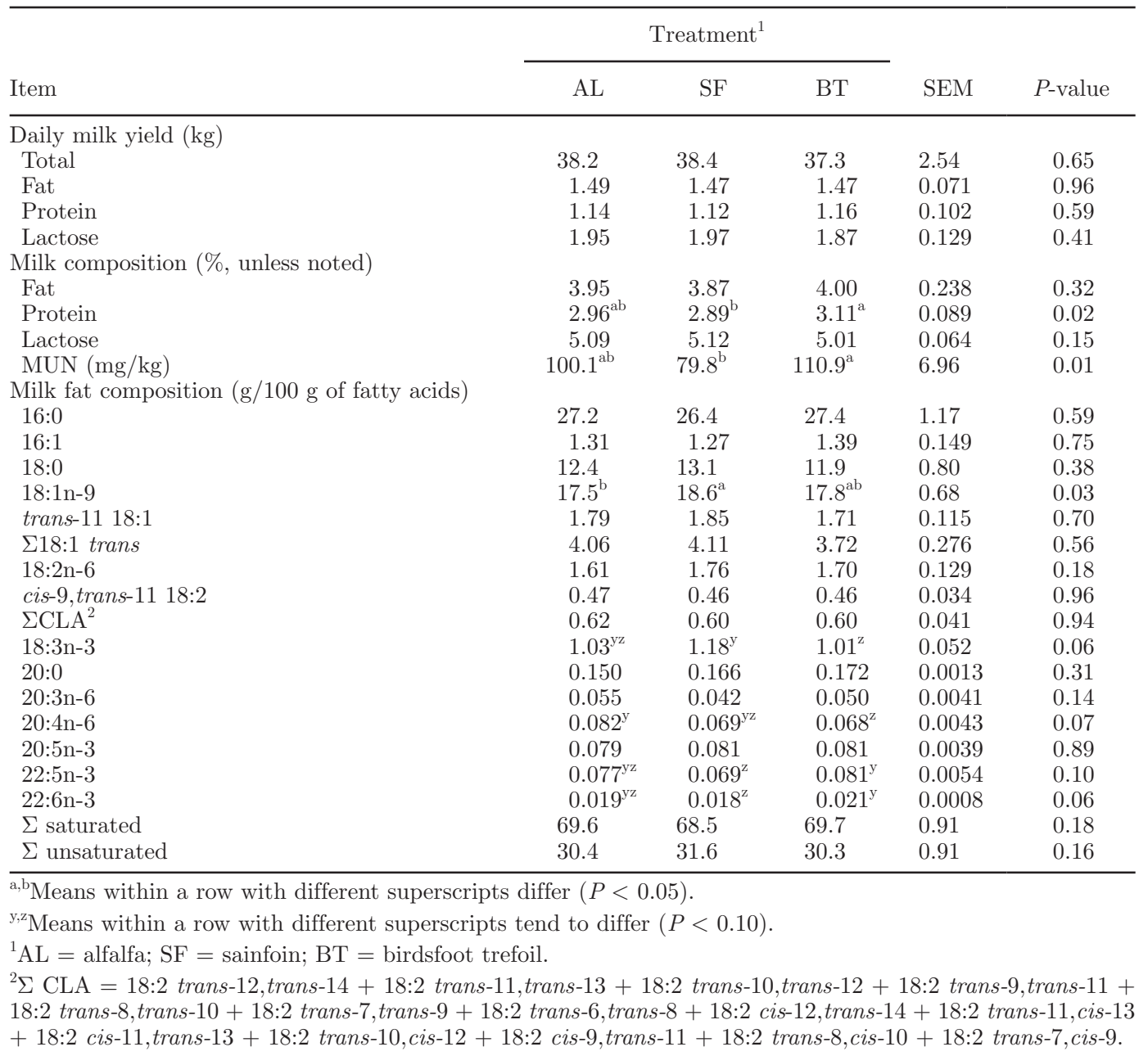

took an intermediate position. Holotrich counts were similar among treatments. The abundance of Prevotella spp. relative to total bacterial $16 \mathrm{~S}$ rDNA was lower $(P$ $<0.05)$ and that of Ruminococcus flavefaciens tended $(P<0.10)$ to be lower in SF cows when compared with AL cows, whereas BT cows took an intermediate position. The relative abundance of the other bacterial species was similar among treatments.

The relative abundance of the MCT1 gene in the ruminal papillae was higher $(P<0.05)$ in BT compared with $\mathrm{SF}$ and $\mathrm{AL}$ cows (Figure 1). The relative abundance of the NHE1, NHE3, and UTB1 genes did not differ among treatments.

Intake and fecal excretion of $\mathrm{N}$ were similar among treatments (Table 6). However, when expressed as a percentage of $\mathrm{N}$ intake, the fecal $\mathrm{N}$ tended $(P<0.01)$ to be higher in $\mathrm{SF}$ than in BT cows, but not in $\mathrm{AL}$ cows. The absolute urinary $\mathrm{N}$ excretion $(P<0.05)$ and its percentage of $\mathrm{N}$ intake were lower $(P<0.05)$ in $\mathrm{SF}$ than in AL cows, but not in BT cows. This shift was accompanied by concomitant changes in urinary urea $\mathrm{N}$ excretion $(P<0.05)$ and the proportion of urea $\mathrm{N}$ in total urinary $\mathrm{N}(P<0.01)$. The sum of fecal and urinary $\mathrm{N}$ excretion, both in absolute amounts or expressed as a percentage of $\mathrm{N}$ intake, did not differ among treatments. Milk N excretion was similar among treatments, both when expressed in absolute amounts or as a percentage of $\mathrm{N}$ intake. Body $\mathrm{N}$ retention was positive for all treatments, but tended $(P<0.01)$ to be lower in SF than in BT cows, whereas AL cows took an intermediate position.

\section{DISCUSSION}

The CT content of the SF in the present study was extraordinarily high when compared with values reported in other studies that used the same cultivar and applied the HCl-butanol method for the analysis of CT (Azuhnwi et al., 2011; Theodoridou et al., 2012). However, the growing period of our SF was characterized 
by high temperatures (average $22.5^{\circ} \mathrm{C}$ ), which can cause an increase in CT content (Ushio and Adams, 2011). Azuhnwi et al. (2011) also showed that CT content in SF increases in the second compared with the first harvest. The climatic conditions had apparently less effect on the CT production in BT; the method used for $\mathrm{CT}$ analysis also has to be treated with caution. The most serious issue in the $\mathrm{HCl}$-butanol method is the use of the standard, as every CT structure gives a different color intensity (Mueller-Harvey, 2006). We counteracted this by producing each standard from the plant itself by extracting with acetone and water $(7: 3, \mathrm{vol} /$ vol) and purification on a Sephadex column (SigmaAldrich). The purification step separates CT, but does not remove other polyphenols and sugars, which will be present in the standard. We performed the purification step twice to reduce the amount of compounds other than CT, but still faced an overestimation of the CT content. Nevertheless, no other reliable method is available to differentiate soluble, protein-bound, and fiber-bound CT.

When we took a closer look at the CT in SF and BT we observed effects due not only to the large difference in $\mathrm{CT}$ content but to differences in the $\mathrm{CT}$ structure. We noted a difference in the proportions of $\mathrm{CT}$ bound to protein and fiber (37 and $62 \%$ for SF and BT, respectively), and in the proportion of soluble $\mathrm{CT}$ (63 and $38 \%$ for SF and BT, respectively). Additionally, the structure of CT (i.e., the proportions of prodelphinidins and procyanidins) is known to differ between $\mathrm{SF}$ and BT. The prodelphinidins occur most frequently in $\mathrm{SF}$, whereas the procyanidins predominate in BT (Mueller-Harvey, 2006). Barry and McNabb (1999) stated that CT, up to a concentration of $90 \mathrm{~g} / \mathrm{kg}$ of $\mathrm{DM}$ in plants, bind with the protein originating from the plant itself, but $\mathrm{CT}$ above this concentration will act as free $\mathrm{CT}$ and may interact with other nutrients in the feed mixture or with ruminal microbes. This might also explain the different effects of SF and BT, because the CT content of SF was higher than this threshold, whereas that of BT was below it.

The forage quality achieved with the $2 \mathrm{CT}$ legumes can be considered equivalent to that of the non-CT legume, AL. This is obvious from the similar performance of the cows when fed a substantial proportion of these legumes in the form of small pellets. For that reason, the effects found in several traits can be associated with the specific properties of these plants, and especially their CT.

\section{Effects on Ruminal Fiber Fermentation and Total-Tract Digestion}

Supplementation of CT can decrease carbohydrate fermentation (Carulla et al., 2005) due to the formation of complexes between $\mathrm{CT}$ and cellulose, hemicellulose,

Table 5. Effect of the type of legume pellets on BUN content and various ruminal fluid variables, counted ciliate protozoa and bacterial species

\begin{tabular}{|c|c|c|c|c|c|c|}
\hline \multirow[b]{2}{*}{ Item } & \multicolumn{3}{|c|}{ Treatment $^{1}$} & \multirow[b]{2}{*}{ SEM } & \multicolumn{2}{|c|}{$P$-value } \\
\hline & $\mathrm{AL}$ & $\mathrm{SF}$ & $\mathrm{BT}$ & & Treatment & Time \\
\hline $\mathrm{BUN}(\mathrm{mmol} / \mathrm{L})$ & $3.45^{\mathrm{a}}$ & $2.71^{\mathrm{b}}$ & $3.90^{\mathrm{a}}$ & 0.170 & $<0.001$ & 0.04 \\
\hline Ammonia $\mathrm{N}^{\prime}(\mathrm{mmol} / \mathrm{L})$ & $3.80^{\mathrm{xy}}$ & $3.01^{\mathrm{y}}$ & $4.51^{\mathrm{x}}$ & 0.475 & 0.10 & 0.002 \\
\hline $\mathrm{VFA}(\mathrm{mmol} / \mathrm{L})$ & $122^{\mathrm{a}}$ & $107^{\mathrm{b}}$ & $119^{\mathrm{ab}}$ & 4.2 & 0.03 & $<0.001$ \\
\hline \multicolumn{7}{|l|}{ VFA (molar percent) } \\
\hline Acetate & 64.4 & 64.4 & 62.6 & 0.81 & 0.22 & $<0.001$ \\
\hline Propionate & 20.4 & 20.0 & 21.4 & 0.77 & 0.44 & $<0.001$ \\
\hline n-Butyrate & 12.4 & 12.9 & 13.0 & 0.30 & 0.37 & 0.13 \\
\hline Isobutyrate & 0.55 & 0.58 & 0.55 & 0.025 & 0.66 & $<0.001$ \\
\hline n-Valerate & $1.34^{\mathrm{ab}}$ & $1.18^{\mathrm{b}}$ & $1.55^{\mathrm{a}}$ & 0.099 & 0.04 & 0.06 \\
\hline Isovalerate & 0.87 & 0.87 & 0.91 & 0.076 & 0.89 & 0.05 \\
\hline \multicolumn{7}{|c|}{ Ciliate protozoa counts (per mL) } \\
\hline Total $\left(\times 10^{5}\right)$ & $1.32^{\mathrm{ab}}$ & $1.71^{\mathrm{a}}$ & $1.22^{\mathrm{b}}$ & 0.127 & 0.02 & 0.45 \\
\hline Entodiniomorphids $\left(\times 10^{5}\right)$ & $1.24^{\mathrm{ab}}$ & $1.65^{\mathrm{a}}$ & $1.14^{\mathrm{b}}$ & 0.122 & 0.01 & 0.35 \\
\hline Holotrichs $\left(\times 10^{3}\right)$ & 7.69 & 6.20 & 8.06 & 1.481 & 0.65 & 0.24 \\
\hline \multicolumn{7}{|c|}{ Bacterial species ( $\%$ of total $16 \mathrm{~S}$ rDNA) ${ }^{2}$} \\
\hline Prevotella spp. & $54.9^{\mathrm{a}}$ & $43.7^{\mathrm{b}}$ & $46.5^{\mathrm{ab}}$ & 2.66 & 0.02 & 0.72 \\
\hline Ruminococcus flavefaciens & $1.73^{\mathrm{y}}$ & $1.34^{\mathrm{z}}$ & $1.45^{\mathrm{yz}}$ & 0.118 & 0.07 & 0.61 \\
\hline Ruminococcus albus & 0.01 & 0.01 & 0.01 & 0.001 & 0.13 & 0.58 \\
\hline Fibrobacter succinogenes & 2.40 & 2.87 & 2.18 & 0.267 & 0.20 & 0.58 \\
\hline Butyrivibrio fibrisolvens & 0.07 & 0.06 & 0.06 & 0.006 & 0.60 & 0.59 \\
\hline
\end{tabular}

\footnotetext{
a,b Means within a row with different superscripts differ $(P<0.5)$.

${ }^{\mathrm{x}, \mathrm{y}}$ Means within a row with different superscripts tend to differ $(P<0.10)$.

${ }^{1} \mathrm{AL}=$ alfalfa; $\mathrm{SF}=$ sainfoin; $\mathrm{BT}=$ birdsfoot trefoil.

${ }^{2}$ Relative abundance of bacterial $16 \mathrm{~S}$ rDNA.
} 

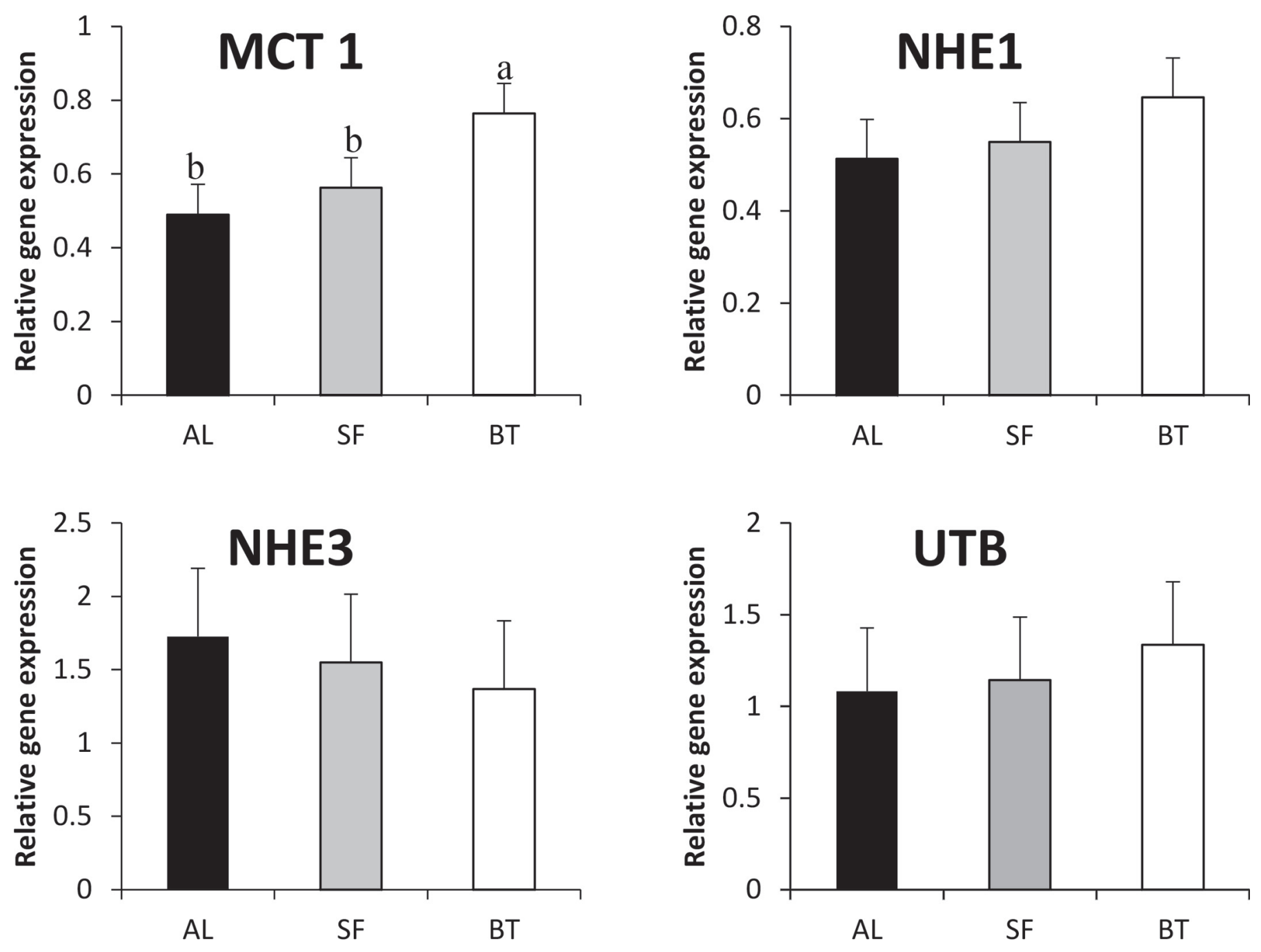

Figure 1. Effect of feeding alfalfa (AL), sainfoin (SF), or birdsfoot trefoil (BT) as pellets on the relative gene expression in the ruminal papillae of monocarboxylate co-transporter isoform (MCT) 1 (treatment: $P=0.01$; time: $P=0.04 ; \mathrm{SEM}=0.08$ ), sodium hydrogen exchanger isoform (NHE) 1 (treatment: $P=0.29$; time: $P=0.17$; SEM $=0.08$ ), NHE3 (treatment: $P=0.75$; time: $P=0.22 ; \mathrm{SEM}=0.47$ ), and urea transporter $\mathrm{B}$ (UTB; treatment: $P=0.75$; time: $P=0.29$; SEM $=0.34$ ). Least squares means with different letters $(\mathrm{a}, \mathrm{b})$ differ $(P<0.05)$.

and pectin (McSweeney et al., 2001). Accordingly, decreases in fiber digestibility are likely when feeding CT-containing legumes (Scharenberg et al., 2007a) or supplementing with CT extracts (Carulla et al., 2005). Concomitantly, the pattern of ruminal VFA often changes, reflecting a decrease in the proportion of acetate, when CT extracts are supplemented to the feed (Carulla et al., 2005; Beauchemin et al., 2007). The ruminal VFA pattern in the present study remained almost unchanged, whereas the content of total ruminal VFA decreased, after SF feeding. However, total-tract fiber digestibility showed no negative effects, which suggested a shift of fiber fermentation to the hindgut. The exact mechanism by which $\mathrm{CT}$ decrease ruminal degradation of carbohydrates remains unclear. On the one hand, CT form complexes with feed particles, thereby prevent- ing microbial attachment (Scalbert, 1991; McSweeney et al., 2001); on the other hand, CT bind to the cell walls of the microbes and inhibit cell-associated enzyme activity (Jones et al., 1994). Tannins are also known to bind to metal ions, which could limit mineral ion availability to the microbes (Scalbert, 1991). Nevertheless, some microbes seem to have greater tolerance to CT than others. We observed a decrease in the prevalence of the carbohydrate-degrading bacteria, Prevotella spp. and Ruminococcus flavefaciens, in SF-fed cows compared with AL-fed cows, whereas the other bacterial strains were not affected. Scalbert (1991) pointed out that some microorganisms may secrete polymers with high affinity to tannins as a protection mechanism, and Jones et al. (1994) stated that the cellulolytic (and the proteolytic) activity of microbes can continue when CT 
Table 6. Effect of the type of legume pellets on the $\mathrm{N}$ balance

\begin{tabular}{|c|c|c|c|c|c|}
\hline \multirow[b]{2}{*}{ Item } & \multicolumn{3}{|c|}{ Treatment $^{1}$} & \multirow[b]{2}{*}{ SEM } & \multirow[b]{2}{*}{$P$-value } \\
\hline & $\mathrm{AL}$ & $\mathrm{SF}$ & $\mathrm{BT}$ & & \\
\hline \multicolumn{6}{|l|}{$\mathrm{N}$ balance $(\mathrm{g} / \mathrm{d})$} \\
\hline Intake & 479 & 459 & 493 & 28.7 & 0.21 \\
\hline Fecal N & 199 & 207 & 192 & 28.8 & 0.28 \\
\hline Urinary N & $98.3^{\mathrm{a}}$ & $79.4^{\mathrm{b}}$ & $93.5^{\mathrm{ab}}$ & 8.04 & 0.04 \\
\hline Urinary urea $\mathrm{N}$ & $66.1^{\mathrm{a}}$ & $41.2^{\mathrm{b}}$ & $74.7^{\mathrm{a}}$ & 8.08 & 0.01 \\
\hline Fecal $\mathrm{N}$ and urinary $\mathrm{N}$ & 297 & 286 & 285 & 26.1 & 0.29 \\
\hline Milk N & 173 & 173 & 179 & 15.9 & 0.69 \\
\hline Body N retention & $9^{\mathrm{yz}}$ & $1^{\mathrm{z}}$ & $29^{y}$ & 0.4 & 0.06 \\
\hline \multicolumn{6}{|l|}{$\mathrm{N}$ balance ( $\%$ of $\mathrm{N}$ intake) } \\
\hline Fecal N & $41.3^{\mathrm{yz}}$ & $45.2^{\mathrm{y}}$ & $38.5^{\mathrm{z}}$ & 2.86 & 0.09 \\
\hline Urinary N & $20.8^{\mathrm{a}}$ & $17.5^{\mathrm{b}}$ & $19.5^{\mathrm{ab}}$ & 1.64 & 0.04 \\
\hline Fecal N and urinary $\mathrm{N}$ & 62.1 & 62.7 & 57.9 & 2.53 & 0.15 \\
\hline Milk N & 35.8 & 37.4 & 36.1 & 1.35 & 0.39 \\
\hline Urinary urea N (\% of total urinary $\mathrm{N}$ ) & $66.3^{\mathrm{ab}}$ & $51.8^{\mathrm{b}}$ & $79.0^{\mathrm{a}}$ & $\begin{array}{l}1.00 \\
4.25\end{array}$ & 0.005 \\
\hline Urinary $\mathrm{N}$ (\% of fecal $\mathrm{N}$ and urinary $\mathrm{N}$ ) & $33.6^{\mathrm{y}}$ & $28.5^{\mathrm{z}}$ & $33.5^{\mathrm{y}}$ & 2.80 & 0.08 \\
\hline
\end{tabular}

levels are low. This indicates that the $\mathrm{CT}$ content of BT might be too low to obtain the same effects seen with SF.

\section{Effects on Indicators of Nutrient Absorption Through the Ruminal Wall}

The absorption of nutrients from the rumen via the blood vessels and into the cells is assisted by nutrient transporters present in the ruminal papillae. We therefore examined the gene expression of the MCT1 transporter, which regulates the diffusion of monocarboxylates (e.g., acetate, lactate, and butyrate), as well as the ketone bodies, together with protons, in the ruminal epithelium (Kirat et al., 2006). A higher content of VFA in the ruminal fluid (which would decrease the rumen $\mathrm{pH}$ ) was reported to upregulate the expression the MCT1 gene in the epithelium (Yan et al., 2014). Consistent with this, we observed that the relative abundance of the $M C T 1$ gene was greatest in BT cows, where VFA content was numerically the highest. Furthermore, the average $\mathrm{pH}$ and the minimum $\mathrm{pH}$ were numerically the lowest in the BT cows, and the time when the $\mathrm{pH}$ was below 5.8 was numerically the longest in the BT cows (data not shown). Whether this effect is directly related to the $\mathrm{CT}$, or whether it reflects other effects, such as location and enumeration of the transporter in the different epithelium layers (Kirat et al., 2006), is not clear. None of the other transporters investigated showed changes in gene expression, showing that neither CT plant had any adverse effect on the function of the ruminal wall transporter system.

\section{Effects on Milk Fatty Acid Composition}

We observed an increase in the proportion of 18:3n-3 in milk fat by SF, which resulted in a numerically higher transfer rate. Accordingly, SF appears to have protected a part of the 18:3n-3 from ruminal $\mathrm{BH}$. By contrast, an unknown mechanism appeared to promote chain elongation and desaturation of n-3 PUFA, because the proportions of $22: 5 n-3$ and $22: 6 n-3$ showed a trend toward an increase in the milk of the BT cows. Conversely, the numerically greater 18:2n-6 and lower 20:4n-6 levels in milk fat of the SF and BT groups suggest that elongation and desaturation rate of n- 6 PUFA is decelerated in the $\mathrm{SF}$ and $\mathrm{BT}$ cows, compared with the AL cows.

If ruminal $\mathrm{BH}$ cannot be avoided, its deceleration or interruption at certain steps may still be advantageous, because some intermediates can also have benefits. As previously shown, CT may lead to an accumulation of trans-11 18:1 (Khiaosa-Ard et al., 2009) and decrease the formation of the terminal product of $\mathrm{BH}, 18: 0$ (Vasta et al., 2009). We observed no effect on the conversion of 18:3n-3 and 18:2n-6 into trans-11 18:1 and 18:0 in the present study. The same result was reported by Khiaosa-Ard et al. (2009) when SF as a whole plant was incubated, whereas this differed with CT extracts from acacia and quebracho (Khiaosa-Ard et al., 2009; Vasta et al., 2009). Nevertheless, the proportion of the 18:1n-9 in milk fat, which can be produced in the mammary gland from 18:0, was highest in the SF cows in the present study.

The BH of PUFA to SFA is mainly done by microbes of the Butyrivibrio genus (Vasta et al., 2010), with Bu- 
tyrivibrio fibrisolvens being responsible for converting PUFA into trans-11 18:1 (Vasta et al., 2010). However, the abundance of $B$. fibrisolvens was not affected in the present study, which is in line with the lack of changes observed in the $\mathrm{BH}$ intermediates in the milk fat. Protozoa, or bacteria associated with them, are also postulated to play a role in BH (Khiaosa-Ard et al., 2009). The numbers of ciliate protozoa were greater in the SF and in the BT cows in the present study, which contradicts the findings of Vasta et al. (2010), who reported no effects on ciliate protozoa populations when feeding quebracho tannin extracts. These opposing results reflect the present lack of knowledge needed to explain how $\mathrm{CT}$ affect ciliate protozoa. The changes in the ciliate protozoa population caused by the CT plants in the present study were obviously too small to generate differences in ruminal $\mathrm{BH}$.

\section{Effects on N Turnover}

The use of CT is one way of efficiently reducing ruminal protein degradation by binding up the protein (e.g., Hagerman and Butler, 1981) under ruminal pH conditions; this can therefore counteract an excess of RDP as the microbes are not able to degrade CT (McSweeney et al., 2001) or CT-protein complexes. In the present study, we observed that SF, but not BT, fulfilled this purpose, as evident from the changes determined in ruminal ammonia, BUN, and MUN. Lower ruminal ammonia and BUN levels have been repeatedly observed when feeding SF (e.g., Scharenberg et al., 2007a; Arrigo and Dohme, 2009; Azuhnwi et al., 2013). The declining content in ruminal ammonia in SF cows was also associated with a lower proportion of valerate, a VFA originating from protein degradation. This is in line with a decrease in the relative abundance of the protein-degrading bacteria, Prevotella spp., in the SF cows. By contrast, a simultaneous decrease in urea in BUN, MUN, and urine of dairy cows fed BT was only shown by Hymes-Fecht et al. (2013). The lack of effect from $\mathrm{BT}$ in the present study must have resulted from the low CT content of the BT used.

Complexes with CT are released below pH 4 (Mangan, 1988), as is the case in the abomasum, so that the protein protected from ruminal degradation can ideally be digested in the intestine (Waghorn, 2008), thereby contributing to the metabolic protein supply. However, in reality, with $\mathrm{CT}$ this phenomenon rarely results in a substantially better $\mathrm{N}$ utilization, likely due to an incomplete separation of the CT-protein complexes (Beauchemin et al., 2007). We also observed a decrease in the apparent total-tract $\mathrm{N}$ digestibility in the present study, and feeding the high-CT plant (SF) did not elevate $\mathrm{N}$ retention in the milk or the body. The BT cows showed a slight increase in body $\mathrm{N}$ retention at the same $\mathrm{N}$ excretion and a slightly higher $\mathrm{N}$ intake. This suggests that these animals might have received additional protein for maintenance or gaining BW, but this appears not to be a CT content-related effect considering the huge difference in CT levels between the 2 legumes.

For that reason, a full compensation occurs in the lowered $\mathrm{N}$ excretion in the urine, in the form of fecal $\mathrm{N}$, as has been observed repeatedly when feeding SF to sheep (e.g., Scharenberg et al., 2007a; Azuhnwi et al., 2013). This is of great relevance for an environmentally friendly animal husbandry, as less gaseous (nitrous oxide and ammonia emissions) and liquid (nitrate leaching) $\mathrm{N}$ is emitted (Dijkstra et al., 2013). In addition, Dijkstra et al. (2013) showed that decreasing the urea $\mathrm{N}$ proportion of total urinary $\mathrm{N}$, as in the present study with SF, has a great potential for reducing the $\mathrm{N}$ emission potential because other compounds present in urine are less prone to generate emissions.

\section{CONCLUSIONS}

Replacing AL with SF at $20 \%$ of the basal diet resulted in some effects on protein turnover, with changes also taking place in the ruminal microbial community. This reduced the $\mathrm{N}$ emission potential of the manure. Although the effect on the milk fatty acid profile was minor, the proportion of 18:3n-3 was slightly increased with SF, possibly due to a numerically higher transfer from the feed to the milk. By contrast, the effects of the same amount of BT were limited. Feeding BT seemed to enhance the amount of protein arriving in the intestine, and thereby protein utilization, especially for body protein retention. The structure and activity of the CT present in the 2 tanniferous forage legumes differed, but the different effects were likely due to the large differences in the CT contents. The SF cultivar and growing conditions favored a very high $\mathrm{CT}$ content (a proportion in the total diet of $3.6 \%$ ), so that $\mathrm{CT}$ effects could be expected. With BT, the resulting $0.5 \% \mathrm{CT}$ in the diet was probably too low to have much effect. Further studies should concentrate on setting maximal dietary proportions of these legumes and dietary CT content, to maximize the effects on desired traits without adversely affecting performance. Comparisons of the 2 tanniferous forage legumes in terms of effects of their CT structures will require future experiments using diets with similar CT content.

\section{ACKNOWLEDGMENTS}

This study was supported by the EU Marie $\mathrm{Cu}$ rie Initial Training Network (LegumePlus; PITN- 
GA-2011-289377). The authors are grateful to the Analytic and Animal Biology Department at Agroscope in Posieux for their assistance.

\section{REFERENCES}

Agroscope. 2014. Futterungsempfehlungen und Nahrwerttabellen fur Wiederkauer (Feeding recommendations and nutrient tables for ruminants). Accessed May 6, 2015. http://www.agroscope.admin. ch/futtermitteldatenbank/04834/index.html?lang=de.

Ampuero-Kragten, S., M. Collomb, S. Dubois, and P. Stoll. 2014 Composition des acides gras dans l'alimentation animale-Méthodes d'analyse. Rech. Agron. Suisse 5:330-337.

AOAC International. 1995. Official Methods of Analysis. 16th ed. AOAC International Arlington, VA.

Arrigo, Y., and F. Dohme. 2009. Esparsette und Luzerne als Beifutter für weidende Kühe (Sainfoin versus alfalfa as supplements for grazing cows). Agrarforschung 16:442-447.

Azuhnwi, B. N., B. Boller, M. Martens, F. Dohme-Meier, S. Ampuero, S. Günter, M. Kreuzer, and H. D. Hess. 2011. Morphology, tannin concentration and forage value of 15 swiss accessions of sainfoin (Onobrychis viciifolia Scop.) as influenced by harvest time and cultivation site. Grass Forage Sci. 66:474-487.

Azuhnwi, B. N., H. Hertzberg, Y. Arrigo, A. Gutzwiller, H. D. Hess, I. Mueller-Harvey, P. R. Torgerson, M. Kreuzer, and F. Dohme-Meier. 2013. Investigation of sainfoin (Onobrychis viviifolia) cultivar differences on nitrogen balance and fecal egg count in artificially infected lambs. J. Anim. Sci. 91:2343-2354.

Barry, T. N., and W. C. McNabb. 1999. The implications of condensed tannins on the nutritive value of temperate forage fed to ruminants. Br. J. Nutr. 81:263-272.

Beauchemin, K. A., S. M. McGinn, T. F. Martinez, and T. A. McAllister. 2007. Use of condensed tannin extract from quebracho trees to reduce methane emissions from cattle. J. Anim. Sci. 85:1990-1996.

Bruinenberg, M. H., R. L. G. Zom, and H. Valk. 2002. Energy evaluation of fresh grass in the diets of lactating dairy cows. Neth. J. Agric. Sci. 50:67-81.

Carulla, J. E., M. Kreuzer, A. Machmüller, and H. D. Hess. 2005. Supplementation of Acacia mearnsii tannins decreases methanogenesis and urinary nitrogen in forage-fed sheep. Aust. J. Agric. Res. 56:961-970.

Dijkstra, J., O. Oenema, J. W. van Groenigen, J. W. Spek, A. M. van Vuuren, and A. Bannink. 2013. Diet effects on urine composition of cattle and $\mathrm{N}_{2} \mathrm{O}$ emissions. Animal 7:292-302.

Dillon, P., J. R. Roche, L. Shalloo, and B. Horan. 2005. Optimising financial returns from grazing in temperate pastures. Pages 131147 in Utilisation of Grazed Grass in Temperate Animal Systems. Proc. Satellite Workshop, 20th Int. Grassl. Congr. Cork, Ireland. Wageningen Academic Publishers, Wageningen, the Netherlands.

Girard, M., F. Dohme-Meier, D. Wechsler, D. Goy, M. Kreuzer, and G. Bee. 2016. Ability of three tanniferous forage legumes to modify quality of milk and Gruyère-type cheese. J. Dairy Sci. 99:205-220.

Hagerman, A. E., and L. G. Butler. 1981. The specificity of proanthocyanidin-protein interactions. J. Biol. Chem. 256:4494-4497.

Harris, S. L., D. A. Clark, and P. J. Laboyrie. 1998. Birdsfoot trefoilAn alternative legume for New Zealand dairy pasture. Proc. N.Z. Grassl. Assoc. 60:99-103.

Hoste, H., J. F. J. Torres-Acosta, C. A. Sandoval-Castro, I. MuellerHarvey, S. Sotiraki, H. Louvandini, S. H. Thamsborg, and T. H. Terrill. 2015. Tannin containing legumes as model for nutraceuticals against digestive parasite in livestock. Vet. Parasitol. 212:5-17.

Hymes-Fecht, U. C., G. A. Broderick, R. E. Muck, and J. H. Grabber 2013. Replacing alfalfa or red clover silage with birdsfoot trefoil silage in total mixed rations increases production of lactating dairy cows. J. Dairy Sci. 96:460-469.

Jones, G. A., T. A. McAllister, A. D. Muir, and K. J. Cheng. 1994. Effects of sainfoin (Onobrychis viciifolia Scop.) condensed tannins on growth and proteolysis by four strains of ruminal bacteria. Appl. Environ. Microbiol. 60:1374-1378.

Khiaosa-Ard, R., S. F. Bryner, M. R. L. Scheeder, H. R. Wettstein, F. Leiber, M. Kreuzer, and C. R. Soliva. 2009. Evidence for the inhibition of the terminal step of ruminal $\alpha$-linolenic acid biohydrogenation by condensed tannins. J. Dairy Sci. 92:177-188.

Kirat, D., J. Masuoka, H. Hayashi, H. Iwano, H. Yokota, H. Taniyama, and S. Kato. 2006. Monocarboxylate transporter 1 (MCT1) plays a direct role in short-chain fatty acids absorption in caprine rumen. J. Physiol. 576:635-647.

Lobley, G. E., A. Connell, M. A. Lomax, D. S. Brown, E. Milne, A. G. Calder, and D. A. H. Farningham. 1995. Hepatic detoxification of ammonia in the ovine liver: Possible consequences for amino acid catabolism. Br. J. Nutr. 73:667-685.

Mangan, J. L. 1988. Nutritional effects of tannins in animal feeds. Nutr. Res. Rev. 1:209-231.

McSweeney, C. S., B. Palmer, D. M. McNeill, and D. O. Krause. 2001 Microbial interactions with tannins: Nutritional consequences for ruminants. Anim. Feed Sci. Technol. 91:83-93.

Mueller-Harvey, I. 2006. Unravelling the conundrum of tannins in animal nutrition and health. J. Sci. Food Agric. 86:2010-2037.

Roseler, A. K., J. D. Ferguson, C. J. Sniffen, and J. Herrema. 1993 Dietary protein degradability effects on plasma and milk urea nitrogen and milk nonprotein nitrogen in Holstein cows. J. Dairy Sci. 76:525-534.

Salminen, J.-P., and M. Karonen. 2011. Chemical ecology of tannins and other phenolics: We need a change in approach. Funct. Ecol $25: 325-338$

Scalbert, A. 1991. Antimicrobial properties of tannins. Phytochemistry 30:3875-3883

Scharenberg, A., Y. Arrigo, A. Gutzwiller, C. R. Soliva, U. Wyss, M. Kreuzer, and F. Dohme. 2007b. Palatability in sheep and in vitro nutritional value of dried and ensiled sainfoin (Onobrychis viciifolia), birdsfoot trefoil (Lotus corniculatus), and chicory (Cichorium intybus). Arch. Anim. Nutr. 61:481-496.

Scharenberg, A., Y. Arrigo, A. Gutzwiller, U. Wyss, H. D. Hess, M. Kreuzer, and F. Dohme. 2007a. Effect of feeding dehydrated and ensiled tanniferous sainfoin (Onobrychis viciifolia) on nitrogen and mineral digestion and metabolism of lambs. Arch. Anim. Nutr. 61:390-405.

Scharenberg, A., M. Kreuzer, and F. Dohme. 2009. Suitability of sainfoin (Onobrychis viciifolia) hay as a supplement to fresh grass in dairy cows. Asian-australas. J. Anim. Sci. 22:1005-1015.

Spek, J. W., A. Bannink, G. Gort, W. H. Hendriks, and J. Dijkstra. 2013. Interaction between dietary concentration of protein and sodium chloride on milk urea concentration, urinary urea excretion, renal recycling of urea, and urea transfer to the gastro intestinal tract in dary cows. J. Dairy Sci. 96:5734-5745.

Terrill, T. H., A. M. Rowan, G. B. Douglas, and T. N. Barry. 1992 Determination of extractable and bound condensed tannin concentrations in forage plants, protein concentrate meals and cereal grains. J. Sci. Food Agric. 58:321-329.

Thanner, S., F. Dohme-Meier, S. Görs, C. C. Metges, R. M. Bruckmaier, and F. Schori. 2014. The energy expenditure of 2 Holstein cow strains in an organic grazing system. J. Dairy Sci. 97:2789-2799.

Theodoridou, K., J. Aufrere, D. Andueza, A. Le Morvan, F. Picard, J. Pourrat, and R. Baumont. 2012. Effects of condensed tannins in wrapped silage bales of sainfoin (Onobrychis viviifolia) on in vivo and in situ digestion in sheep. Animal 6:245-253.

Tiemann, T. T., L. H. Franco, G. Ramirez, M. Kreuzer, C. E. Lascano, and H. D. Hess. 2010. Influence of cultivation site and fertilisation on the properties of condensed tannins and in vitro ruminal nutrient degradation of Calliandra calothyrsus, Flemingia macrophylla and Leucaena leucocephala. Anim. Feed Sci. Technol. 157:30-40.

Turner, S.-A., G. C. Waghorn, S. L. Woodward, and N. A. Thomson 2005. Condensed tannins in birdsfoot trefoil (Lotus corniculatus) affect the detailed composition of milk from dairy cows. Proc. N. Z. Soc. Anim Sci. 65:283-289. 
Ushio, M., and J. M. Adams. 2011. A meta-analysis of the global distribution pattern of condensed tannins in tree leaves. Open Ecol. J. 4:18-23.

Vasta, V., H. P. S. Makkar, M. Mele, and A. Priolo. 2009. Ruminal biohydrogenation as affected by tannins in vitro. Br. J. Nutr. 102:82-92.

Vasta, V., D. R. Yanez-Ruiz, M. Mele, A. Serra, G. Luciano, M. Lanza, L. Biondi, and A. Priolo. 2010. Bacterial and protozoal communities and fatty acid profile in the rumen of sheep fed a diet containing added tannins. Appl. Environ. Microbiol. 76:2549-2555.

Waghorn, G. 2008. Beneficial and detrimental effects of dietary condensed tannins for sustainable sheep and goat production-Progress and challenges. Anim. Feed Sci. Technol. 147:116-139.
Woodward, S. L., P. J. Laboyrie, and E. B. L. Jansen. 2000. Lotus corniculatus and condensed tannins - Effects on milk production by dairy cows. Asian-australas. J. Anim. Sci. 13:521-525.

Yan, L., B. Zhang, and Z. Shen. 2014. Dietary modulation of the expression of genes involved in short-chain fatty acid absorption in the rumen epithelium is related to short-chain fatty acid concentration and $\mathrm{pH}$ in the rumen of goats. J. Dairy Sci. 97:5668-5675.

Ye, J., G. Coulouris, I. Zaretskaya, I. Cutcutache, S. Rozen, and T. L. Madden. 2012. Primer-BLAST: A tool to design target-specific primers for polymerase chain reaction. BMC Bioinformatics $13: 134$

\section{APPENDIX}

Table A1. Primers used for the quantitative PCR

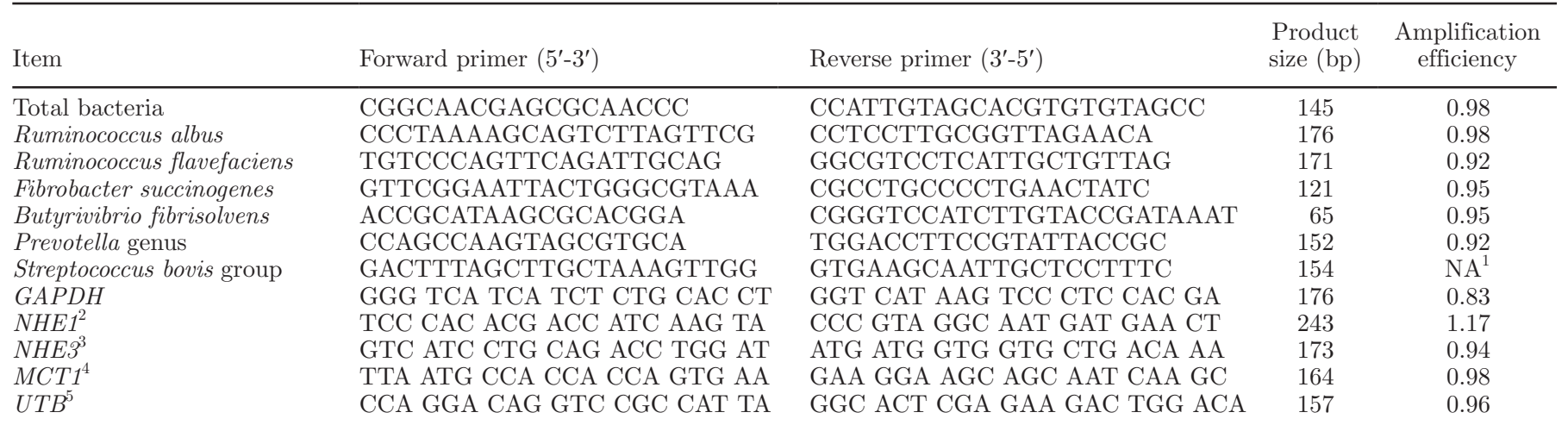

${ }^{1}$ No meaningful efficiency calculation possible due to low abundance of $S$. bovis species. For quantification, efficiency was set to one.

${ }^{2}$ NHE1 = sodium hydrogen exchanger isoform 1.

${ }^{3} \mathrm{NHE} 3=$ sodium hydrogen exchanger isoform 3.

${ }^{4} M C T 1=$ monocarboxylate transporter 1.

${ }^{5} U T B=$ urea transporter B. 